DOI: http://dx.doi.org/10.18203/2320-1770.ijrcog20184932

Original Research Article

\title{
Removed versus unremoved vicryl sutures used for subcuticular skin closure
}

\author{
Suzan S. Elsharkawy ${ }^{1 *}$, Waleed A. Dawood ${ }^{2}$
}

\begin{abstract}
${ }^{1}$ Department of Obstetrics and Gynecology, ${ }^{2}$ Department of Urology, Faculty of Medicine, Alexandria University, Alexandria, Egypt
\end{abstract}

Received: 02 September 2018

Accepted: 01 November 2018

\section{*Correspondence:}

Dr. Suzan S. Elsharkawy,

E-mail: samirsuzan6@gmail.com

Copyright: () the author(s), publisher and licensee Medip Academy. This is an open-access article distributed under the terms of the Creative Commons Attribution Non-Commercial License, which permits unrestricted non-commercial use, distribution, and reproduction in any medium, provided the original work is properly cited.

\section{ABSTRACT}

Background: The objective was to compare the difference between removing vicryl suture thread after skin healing or burry the knots and leaving it to be absorbed in situ, after subcuticular skin closure of Pfannesteil incisions.

Methods: Prospective, randomized controlled trial included 449 eligible participants were prospectively recruited between July 2016 and June 2017. All selected patients had a pfannenstial incision with subcuticular skin closure using 2-0 absorbable vicryl stiches (for primary caesarean section or extra peritoneal surgical approach to the prostate, bladder and distal ureters). The left side knot was buried under the skin edge and a knot in the midline and the right edge was made. After 10 days postoperative, the right half of the stitch thread and the two knots were removed, and the left half of the thread was left in situ. Patients were observed for any complication at time of stitch removal, after one month and after 6 months' post-operative.

Results: Wound infection rate, hypertrophic scars, keloids and skin itching were significantly higher in the unremoved wound sides while skin dehiscence was significantly higher in the removed wound sides.

Conclusions: Leaving behind absorbable suture material after wound healing -when used in subcuticular pfannenstial skin closure- is associated with increased rates of wound infection, hypertrophic scars, itching and keloids, which of course overweight any known benefits of the technique.

Keywords: Hypertrophic scar, Keloid, Surgical wound, Wound healing

\section{INTRODUCTION}

Pfannesteil or lower transverse abdominal incision is one of the most famous abdominal opening techniques, due to its popularity in most of gynecological, obstetrics, and many urological operations. ${ }^{1,2}$ In most of uncomplicated cases, subcuticular skin suturing is used for Pfannesteil wound closure, although it is possible to use stables or adhesive tapes or any other method of skin suturing. The subcuticular terminology is a misnomer, and this technique should be described as intradermal more accurately. ${ }^{3}$ If a running continuous subcuticular suture is applied meticulously, the wound edges will be approximated accurately. This type of suturing is preferred in linear and curvilinear wounds because it does not cause the cross-hatch stitch marks, which are produced by interrupted sutures, as well as maintaining good tensile strength for a long period of time. There are different suturing materials that can be used to close a wound sub-cuticularly. If a non-absorbable suture material is used, the suture will need to be removed once the skin wound has healed properly. Absorbable sutures can be used also with the advantage of having the option to leave the suture buried. This will be of great benefit for some cases especially in pediatric and cognitively impaired patients. ${ }^{4-7}$ Wound healing is an extremely important factor for patient satisfaction after a surgical interference, not only to avoid surgical wound 
complications but also for the best cosmetic result and the scar appearance, it is well known among surgeons that whatever was done inside the abdomen, it will be kept secret if the scar looks good.

The operator experience and technique are the most important factors that can be correlated to scar appearances, the experience of incorporating intraoperative techniques described as the $5 \mathrm{~A}$ 's asepsis: absence of tension, accurate approximation, avoidance of raw surface, and atraumatic tissue handling. Smaller instruments force surgeons to use as possible little traction and crushing forces to handle wound edges. Nonabsorbable sutures are removed as soon as the wound edges have gained the strength to be kept together. Each time, the operator must remember that the suture function is to provide approximation without tension, and the fibroblasts and collagen fibers not sutures will manage to hold the wound together. ${ }^{8}$

Wound healing can be described into three main processes: inflammation, proliferation, and remodelling. Inflammation starts with disruptions in blood vessels, induction of hemostatic cascade and formation of fibrin clots, which paves the way of wound healing cellular process. The proliferation stage begins around day 4 or 5 with the migration of fibroblasts into the wound matrix and continues for the next 2 to 4 weeks, when fibroblasts replace the fibrin with a more robust matrix of collagen fibers. The last stage in wound healing is remodelling phase, which starts 3 weeks after tissue injury, when fibroblasts decrease in number and hardening of collagen fibers takes place. Continuous collagen production and degradation must balance each other, so no significant change in collagen is observed. Wound healing phases are not completely separated. Proliferation phase begins before the inflammation phase has finished and continues after remodelling has begun. The remodelling continues months after the sutures and dressing had been removed. ${ }^{9-}$ 13

As a wound reaches maturity, cytokine signals change for cessation of furthermore collagen synthesis and degradation. Sometimes a number of genetic and environmental factors may interfere with this 'stop' signal, which may lead to continual production of collagen fibers in the wound. Clinically, this response is observed as a hypertrophic scar or less commonly keloid. ${ }^{14}$

A hypertrophic scar has a red elevated surface in relation to normal skin, but the proliferation is never contained outside the margin of the wound. Clinically, hypertrophic scars grow from 3 to 6 months, but most of them begin to lose the redness and shrink in size around 6 months, till two years for the elevated surface to completely flatten. Hypertrophic scars can cause severe pain and pruritus. ${ }^{15}$

The main features distinguishing keloids from hypertrophic scars are: keloid scar grows beyond the original wound margin, turns from red to brown, and behaves like a benign tumor of the skin. ${ }^{16}$

Similar to hypertrophic scars, a keloid is a product of uninhibited deposition of collagen. In keloids, fibroblasts continue to proliferate despite reaching the enough strength of dermal matrix to oppose the tensile forces across the wound. Even after years of research, the exact cause behind keloids remains uncertain. ${ }^{17-21}$

\section{METHODS}

250 women attending Elshatby maternity hospital for primary caesarean section with a pfannenstial skin incision, and 250 middle aged men attending the main university hospital urology department for lower horizontal abdominal incisions (extra peritoneal surgical approach to the prostate, bladder and distal ureters) were prospectively recruited between July 2016 and June 2017. The total number of patients accepted and included in the study period was: 231 females and 218 males with total number of 449 patients. The main reason for exclusion was lack of follow-up in 51 cases $(10.2 \%)$.

All selected patients had subcuticular skin closure with 20 absorbable vicryl stiches (Polyglactic 910). Vicryl is a synthetic, absorbable, braided suture made of polyglactin 910 coated with a copolymer of L-lactide and glycolide (Polyglactin 370) and calcium stearate. Vicryl retains $65 \%$ of its tensile strength at 2 weeks and $40 \%$ at 3 weeks. Complete absorption of Vicryl occurs between 60 and 90 days by hydrolysis. ${ }^{22-24}$

The left side knot was buried under the skin edge and a knot in the midline and the right edge was made. After 10 days postoperative, the right half of the stitch thread and the two knots were removed, and the left half of the thread was left in situ. All patients included in the study were advised not to use any medication that would potentially affect wound healing. All patients were observed for any complication at time of stitch removal, after one month and after 6 months' post-operative.

Wound infection was defined as any discharge required dressing and/or antibiotic use. Wound dehiscence was defined as skin edges separation more than $1 \mathrm{~cm}$ in length. Hematoma was defined as wound swelling with discoloration more than $1 \mathrm{~cm}$ in diameter. Hypertrophic scar was defined as red colored, hard, itchy, visible, and raised from the normal tissue level scar. Keloid was defined as continued scar hypertrophy after 6 months and extended beyond the original wound margin.

Each patient was his/ her own control in the RCT, so patient variations were removed, making the trial potentially more efficient than a similarly sized parallel group design study where each patient receives only one intervention. ${ }^{25}$ The primary outcomes were complications related to wound healing (infection, dehiscence and hematoma formation) at day 10 postoperative and 
hypertrophic scar at one-month follow-up. Secondary outcomes were itching at the scar site and presence of keloids 6 months later.

\section{Exclusion criteria}

- $\quad$ Patients with any positive medical history (diabetes, immune disease, steroid intake, drug allergy).

- Patients with previous lower abdominal incisions.

- Patients having intraoperative or early postoperative complication and emergency surgeries (no time for consenting).

\section{Statistical analysis}

Data were fed to the computer and analyzed using IBM SPSS software package version 20.0. (Armonk, NY: IBM Corp). Qualitative data were described using number and percent. Significance of the obtained results was judged at the 5\% level. The used tests were Chi-square test for categorical variables, to compare between different groups. $^{26,27}$

Ethics: to ensure that the study was carried out in a responsible manner from a research ethical point of view,
RCTs have to be approved by a research ethics committee before it started, and that the rights, safety, and wellbeing of the patients are protected, at the same time, the possibility is being created for the development of recent, valuable knowledge.

\section{RESULTS}

The total number of patients included in the study period was 449. They performed a pfannenstial incision and subcuticular skin closure with 2-0 absorbable vicryl stitches. The left side knot was buried under the skin edge, the right half of the thread was removed 10 days postoperative, and the left half of the thread was left in situ. Comparison between two sides for early and late wound complications was made.

As regard early wound complications; wound infection rate was significantly higher in the un-removed side, wound hematoma rate was higher in the removed side but with no statistical significance, skin dehiscence was significantly higher in the removed side as shown in the table. As regard late wound complications; hypertrophic scar, keloids and skin itching were all significantly higher in the un-removed side as shown in the table.

Table 1: Comparison between the two studied sides according to early and late wound healing complications.

\begin{tabular}{|c|c|c|c|c|c|c|}
\hline \multirow[t]{2}{*}{ Complication } & \multicolumn{2}{|c|}{$\begin{array}{l}\text { Removed thread, right side } \\
(\mathrm{n}=449)\end{array}$} & \multicolumn{2}{|c|}{$\begin{array}{l}\text { Un-removed thread, left side } \\
(n=449)\end{array}$} & \multirow[t]{2}{*}{$\chi^{2}$} & \multirow[t]{2}{*}{ P value } \\
\hline & No. & $\%$ & No. & $\%$ & & \\
\hline $\begin{array}{l}\text { Wound infection } \\
\text { (10 days later) }\end{array}$ & 36 & 8.1 & 103 & 22.8 & $38.209 *$ & $<0.001 *$ \\
\hline $\begin{array}{l}\text { Hematoma } \\
\text { ( } 10 \text { days later) }\end{array}$ & 16 & 3.7 & 12 & 2.6 & 0.590 & 0.442 \\
\hline $\begin{array}{l}\text { Dehiscence } \\
\text { (10 days later) }\end{array}$ & 58 & 12.8 & 19 & 4.2 & $21.606 *$ & $<0.001 *$ \\
\hline $\begin{array}{l}\text { Hypertrophic scar } \\
\text { (1 month later) }\end{array}$ & 42 & 9.5 & 138 & 30.8 & $64.036 *$ & $<0.001 *$ \\
\hline $\begin{array}{l}\text { Keloid } \\
\text { (6 months later) }\end{array}$ & 10 & 2.2 & 51 & 11.4 & $29.566^{*}$ & $<0.001 *$ \\
\hline $\begin{array}{l}\text { Itching } \\
\text { ( } 6 \text { months later) }\end{array}$ & 23 & 5.1 & 147 & 32.6 & $111.568 *$ & $<0.001 *$ \\
\hline
\end{tabular}

$\chi^{2}, \mathrm{p}: \chi^{2}$ and $\mathrm{p}$ values for Chi square test for comparing between the two groups; *: Statistically significant at $\mathrm{p} \leq 0.05$

\section{DISCUSSION}

Skin closure is a fundamental surgical step, because it affects the cosmetic aspect of the surgery and how the skin looks after healing, which is a very important issue for patient satisfaction. Data are lacking in terms of what is the best method for skin closure in cesarean operations. $^{28,29}$

Several studies in the literature compared staples with suture in closure of pfannenstial incisions. ${ }^{30-32}$ A meta- analysis included 877 patients from 5 studies compared staples and subcuticular sutures use. It showed that wound dehiscence and complications were more with staples, recommending that subcuticular closure of the skin. ${ }^{31}$

There is a lack of data comparing types of subcuticular suture materials outcome. Tan et al designed a study comparing the suture material outcome and concluded that both absorbable and non-absorbable sutures are similar in short-term outcomes but non-absorbable 
sutures require removal as a disadvantage while absorbable suture material group suffered from late-term itching at the scar site more frequently due to the late absorption of the left behind suture material. ${ }^{33}$ Hasdemir PS et al showed that there was no significant difference in terms of wound complications between the two suture materials but there is a tendency to get better wound healing with non-absorbable suture materials, although this difference did not affect the patient's satisfaction rate. ${ }^{34}$

After searching literature, there were no similar studies comparing removal versus no removal of absorbable suture materials on wound healing outcomes, in the present study authors found more wound infection, less hematomas, less skin dehiscence and significantly higher rates of late wound healing complications (hypertrophic scar, keloids and itching) in the non-removed absorbable suture material side. These results may be due to the fact that leaving sutures in the wound after skin healing may start a foriegn body reactions which in a significant percentage of patients may cause early and late complications of wound healing process. Such complications can be avoided with the simple and logic procedure of suture removal 7-10 days post-operative.

\section{CONCLUSION}

Authors concluded that non-removal of absorbable suture material after wound healing, when used in subcuticular pfannenstial skin closure is associated with increased rates of wound infection, hypertrophic scars, itching and keloids, which of course overweight any known benefits of the technique.

Funding: No funding sources

Conflict of interest: None declared

Ethical approval: Not required

\section{REFERENCES}

1. Gibbons L, Belizán JM, Lauer JA, Betrán AP, Merialdi M, Althabe F. The global numbers and costs of additionally needed and unnecessary caesarean sections performed per year: overuse as a barrier to universal coverage. World health report. 2010;30:1-31.

2. Tully L, Gates S, Brocklehurst P, McKenzie-McHarg $\mathrm{K}$, Ayers S. Surgical techniques used during caesarean section operations: results of a national survey of practice in the UK. European J Obstet Gynecol Reprod Biol. 2002;102(2):120-6.

3. Mashhadi SA, Loh CYY: Subcuticular suture-is it a misnomer?. Eur J Plastic Surg. 2010;33(4):233.

4. Van den Ende ED, Vriensa PWHE, Allemaa JH, Breslaua PJ. Adhesive bonds or percutaneous absorbable suture for closure of surgical wounds in children. J Pediatr Surg. 2004;39(8):1249-51.

5. Sanders RJ. Subcuticular skin closure, description of technique. J Dermatol Surg. 1975;1:61-4.
6. Moy RL, Waldman B, Hein DW. A review of sutures and suturing techniques. J Dermatol Surg Oncol. 1992;18:785-95.

7. La Padula A. A new technique to secure an entirely buried subcuticular suture. Plast Reconstr Surg. 1995; 95:423.

8. Bush JA, McGrouther DA, Young VL, Herndon DN, Longaker MT, Mustoe TA, et al. Recommendations on clinical proof of efficacy for potential scar prevention and reduction therapies. Wound Repair Regen. 2011;19:32-7.

9. Almine JF, Wise SG, Weiss AS. Elastin signaling in wound repair. Birth Defects Res C Embryo Today. 2012;96:248-57.

10. Bae SH, Bae YC, Nam SB, Choi SJ. A skin fixation method for decreasing the influence of wound contraction on wound healing in a rat model. Arch Plast Surg. 2012;39:457-62.

11. Larson BJ, Longaker MT, Lorenz HP. Scarless fetal wound healing: a basic science review. Plast Reconstr Surg. 2010;126:1172-80.

12. Kim HY, Kim JW, Park JH, Kim JH, Han YS. Personal factors that affect the satisfaction of female patients undergoing esthetic suture after typical thyroidectomy. Arch Plast Surg. 2013;40:414-24.

13. Toll EC, Loizou P, Davis CR, Porter GC, Pothier DD. Scars and satisfaction: do smaller scars improve patient-reported outcome? Eur Arch Otorhinolaryngol. 2012;269:309-13.

14. Bran GM, Goessler UR, Hormann K, Riedel F, Sadick H. Keloids: current concepts of pathogenesis (review). Int J Mol Med. 2009;24:283-93.

15. Juckett G, Hartman-Adams H. Management of keloids and hypertrophic scars. Am Fam Physician. 2009;80:253-60.

16. Oluwasanmi JO. Keloids in the African. Clin Plast Surg. 1974;1:179-95.

17. Appleton I, Brown NJ, Willoughby DA. Apoptosis, necrosis, and proliferation: possible implications in the etiology of keloids. Am J Pathol. 1996;149:14417.

18. Ladin DA, Hou Z, Patel D, McPhail M, Olson JC, Saed GM, et al. P53 and apoptosis alterations in keloids and keloid fibroblasts. Wound Repair Regen. 1998;6:28-37.

19. DiPietro LA. Angiogenesis and scar formation in healing wounds. Curr Opin Rheumatol. 2013;25:8791.

20. Huang C, Akaishi S, Ogawa R. Mechanosignaling pathways in cutaneous scarring. Arch Dermatol Res. 2012;304:589-97.

21. Sarrazy V, Billet F, Micallef L, Coulomb B, Desmoulière A. Mechanisms of pathological scarring: role of myofibroblasts and current developments. Wound Repair Regen. 2011;19:10-5.

22. Ammirati CT. Advances in wound closure material.: In: James WD, ed. Advances in dermatology. 18, St. Louis (MO): Mosby; 2002:313-338.

23. Edlich R, Szarmach RR, Livingston J, Rodeheaver GT, Thacker JG. An innovative surgical suture and 
needle evaluation and selection program. J Long Term Eff Med Implants. 2002;12(4):211-29.

24. Hochberg J, Murray GF. Principles of operative surgery. In: Sabiston DC, ed. Textbook of surgery. $15^{\text {th }}$ ed. Philadelphia: WB Saunders; 1992:253-263.

25. Sibbald B, Roberts C. Understanding controlled trials. Crossover trials. BMJ. 1998;316(7146):1719.

26. Kotz S, Balakrishnan N, Read CB, Vidakovic B. Encyclopedia of statistical sciences. $2^{\text {nd }}$ ed. Hoboken, N.J.: Wiley-Interscience; 2006.

27. Kirkpatrick LA, Feeney BC. A simple guide to IBM SPSS statistics for version 20.0. Student ed. Belmont, Calif.: Wadsworth, Cengage Learning; 2013.

28. Mackeen AD, Berghella V, Larsen ML. Techniques and materials for skin closure in caesarean section. Cochrane Database of Systematic Reviews. 2012(11).

29. Berghella V, Baxter JK, Chauhan SP. Evidencebased surgery for cesarean delivery. Am J Obstet Gynecol. 2005;193(5):1607-17.

30. Alderdice F, McKenna D, Dornan J. Techniques and materials for skin closure in caesarean section. Cochrane Database of Systematic Reviews. 2003(2).
31. Clay FS, Walsh CA, Walsh SR. Staples vs subcuticular sutures for skin closure at cesarean delivery: a metaanalysis of randomized controlled trials. Am J Obstet Gynecol. 2011;204(5):378-83.

32. Mackeen AD, Schuster M, Berghella V. Suture versus staples for skin closure after cesarean: a metaanalysis. Am J Obstet Gynecol. 2015;212(5):621-e1.

33. Tan PC, Mubarak S, Omar SZ. Absorbable versus nonabsorbable sutures for subcuticular skin closure of a transverse suprapubic incision. Int J Gynecol Obstet. 2008;103(2):179-81.

34. Hasdemir PS, Guvenal T, Ozcakir HT, Koyuncu FM, Dinc Horasan G, Erkan M, et al. Comparison of subcuticular suture materials in cesarean skin closure. Surg Res Pract. 2015;2015.

Cite this article as: Elsharkawy SS, Dawood WA. Removed versus unremoved vicryl sutures used for subcuticular skin closure. Int J Reprod Contracept Obstet Gynecol 2018;7:4877-81. 